\title{
COMPETITIVE ANALYSIS OF OUTDOOR ORNAMENTAL PLANTS SECTOR: A CASE STUDY OF KONYA PROVINCE, TURKEY
}

\author{
Yusuf ÇELIK*, Hasan ARISOY \\ Selçuk University, Agricultural Faculty, Department of Agricultural Economics \\ 42079 Konya, Turkey \\ Received: September 8, 2013; Accepted: November 30, 2013
}

\begin{abstract}
In this study, development and alteration trends of ornamental plants sector in Turkey and the rest of the world were analysed. The competitive and structural analysis of outdoor ornamental plants sector in Konya province, Turkey, was carried out in accordance with the Strengths, Weakness, Opportunities, Threats (SWOT) analytical technique and Diamond Model of Porter. Main data of the study have been obtained by a survey method from 16 managers of enterprises. According to the results, the ornamental plants sector in Turkey developed vigorously, especially after 1980s, in parallel with other parts of the world. The cultivated area of ornamental plants in Turkey, which was 1513.2 ha in 2000, tripled to 4786.0 ha in 2011. Outdoor ornamental plants sector in Konya province has developed in parallel with that in the whole country and the number of enterprises producing has increased by $50 \%$ in the last decade. Competition level of outdoor ornamental plants sector is low in Konya. As a strategy to increase it, the aggregation of production in larger companies and diversification of the spectrum of plants more adapted to the natural conditions are discussed.
\end{abstract}

Key words: Outdoor ornamental plants, SWOT, structural analysis, Konya province, Turkey

\section{INTRODUCTION}

In the last century, landscape was considered as an important tool in enhancing life quality of individuals in parallel with the recent developments in urbanization in the world, particularly in developed countries. Today, green area quantity per capita is used as a standard of life quality. The endeavours for increasing green areas in towns and close surroundings resulted in an increase of demand for outdoor ornamental plants (Ay 2009). Arrangement of outdoor areas became an important economic sector, which resulted in an increase in agricultural activities in the sector of ornamental plants production.

Ornamental plants gained importance and came into being in the economic sector in the 20th century. Increase in demand for ornamental plants has led to profitability in this sector, and its continuous growth in developing and developed countries. Specialization, production, marketing, and consumption issues are being handled like the industrial sector. The level of standardization, sustainability, and technology of production has reached a phase where this sector is defined as the 'Ornamental Plants Sector' (Karagüzel et al. 2010).

There has been rapid development and change in the ornamental plants sector in Turkey after the 1980s in parallel with other parts of the world. This development has gained speed in the 2000s. When relevant statistics were examined, the area under ornamental plants production in Turkey increased from 1513.2 ha in the beginning of 2000s to 4786.0 ha in 2011 (Anon. 2012).

Konya is one of the provinces developing rapidly due to its geographical location and natural resources. In Turkey, it is ranked as the seventh in terms of its population and is at the positions 17th, 9th and 23rd in the socio-economic status according to indexes - development, economic development 
and social development, respectively (Eraydin et al. 2012). Moreover, the Konya province is located between important west and east metropolis. It has been found that production of outdoor ornamental plants and flower bulbs is rational due to the ecological and geographical structure of Konya province (Eşitken et al. 2012). There are small- and medium-scaled enterprises in Konya, which produce in order to cover the demand of outdoor ornamental plants. However, specific rules enabling a competitive advantage for ornamental plants sector have not been constituted yet. Determination of the current state and structural analysis of outdoor ornamental plants sector will contribute to its development. Although some regions of Turkey were portrayed (Özen et al. 1998; Anon. 2001; Taşçığlu 2003; Sayın \& Sayın 2004; Yılmaz 2009; Zencirkıran \& Gürbüz 2009; Ay 2009; Karagüzel et al. 2010; Temel 2011; Eşitken et al. 2012; Subaş1 et al. 2012) almost no study was conducted on ornamental plant production in Konya province. In this work, analysis of the outdoor ornamental plants sector of Konya province is given.

\section{MATERIAL AND METHOD}

The primary data of the study were obtained through the survey method from managers of 16 enterprises producing outdoor ornamental plants in Konya province and the secondary information consisted of relative statistics and related studies of the subject.

The Strengths, Weaknesses, Opportunities, Threats (SWOT) analytical technique, and structural analysis of outdoor ornamental plants sector in Konya have been examined through the data that were obtained by the survey method and with the help of relevant literature. SWOT analysis is a brainstorming study carried out on the key factors affecting the success of enterprises in this sector. In the recent years, this has been frequently used for strategy designing and analytical decisions in planning studies, problem description, and problem solving (Houben et al. 1999; Yumuk \& İnan 2005; Zoller \& Bruynis 2007).

Twenty-two criteria were determined to make the SWOT analysis. Based on these criteria, business managers were asked to evaluate the outdoor ornamental plant sectors in Konya and Turkey on a five-point Likert's scale. In this scale, scoring is as follows: 5 - excellent, 4 - very good, 3 - good, 2 - fair, 1 - poor. Criteria taking 3.0-5.0 points from managers of enterprises have been rated as strengths and criteria taking 1.0-2.9 points have been rated as weaknesses in SWOT analysis. Structural analyses of the outdoor ornamental plants sector have been carried out within a five-factors level included in the Diamond Model (Porter 1990; 2004). These factors are input terms, demand conditions, company strategies and competitive structure, relative-supporting institutions and role of state. Components of these five factors were submitted to managers of enterprises within triple scale. In this assessment, -1 was evaluated as low, 0 was evaluated as medium and +1 was evaluated as high. For generalization of data, factors were defined for -1 since the structure of the sector shall be regarded as low in terms of that competition; in the event that it was 0 , structural conditions are normal and if it was 1, structural conditions are high. Taking into account the results of SWOT and structural analysis, competition-enhancing strategies of development of outdoor ornamental plants in Konya province were analysed with regard to Porter's total cost leadership, differentiation and clustering strategy model components (Porter 2003).

\section{RESULTS}

\section{Ornamental plant production trends in the world}

Although cultivation of ornamental plants dates back to ancient times, economically it came into being at the end of the 19th century and in the beginning of the 20th century as a subsector of the plant production sector and such concepts as production, marketing and employment became a part of this sector. Commercial ornamental plants cultivation predominantly started with cut flower production near large cities of developed countries and expanded to include outdoor and indoor ornamental plants.

With the transformation of ornamental plants production to a structural sector, research and 
development activities related to this sector have gained importance and some of the basic knowledge being used today has developed within this area.

After the Second World War stagnation, development in ornamental plants sector started again and spread to the regions having favourable climatic conditions, particularly in developed countries. Transformation in production and commerce of world ornamental plants, particularly of cut flowers, began in the 1970s, when some countries started production oriented towards export of cut flowers using such advantages as suitable climatic conditions or strategic position. For example, Colombia reached the position of a country monopolizing the American market largely. In the 1980s, South Africa, Kenya, Thailand, and Ecuador having appropriate climate advantages began to follow this production policy and their production export increased rapidly. After 1985, Uganda and Turkey were included in this production. After 1990, developed countries, particularly Holland, dislocated their production areas towards Africa (Kenya) and South America (Colombia) that had low labour costs and appropriate climate. These countries started selling considerable part of their production through their own markets and marketing channels (Karagüzel et al. 2010).

Ornamental plant production has been carried out in more than 50 countries in the world. In 2010, total ornamental plants production area was 1423534 ha (Table 1). The highest production takes place in Asia-Pacific, followed by North
America, Europe, South America, Africa, and Middle East. Production of outdoor ornamental plants is carried out on $59 \%$ of the total ornamental plants production area; the remaining 39\% area is under production of cut flowers and indoor ornamental pot plants and $2 \%$ constitutes flower bulbs production. In 2010, value of total ornamental plants production was 47.5 billion Euro, including outdoor ornamental plants at 20.3 billion Euro and flower bulbs at 0.7 billion Euro (Subaş1 et al. 2012).

\section{Ornamental plant production trends in Turkey}

Development of the ornamental plants sector in Turkey started near Istanbul and Yalova where urbanization phenomenon gained speed and then in İzmir in the 1970s; in Antalya in the 1980s; and partially in Adana and Muğla in the beginning of the 1990s. In the 1970s, flower cultivation took place as an alternative besides vegetable production in these regions. Commercial ornamental plant cultivation expanded by including indoor and outdoor ornamental plants (Titiz et al. 2000). In the 1980s, production of ornamental plants entered a new phase.

There has been a rapid advance in all fields of the sector after 1985 due to government subsidies for export of final material and import of propagating material. During this period, the sector entered a new trend with the exports of cut flowers produced in sophisticated greenhouses in Antalya. The revenue came up with the increase in the export of ornamental plants due to changing perception of the producers and the approach towards this sector.

Table 1. Ornamental plant production area in the world (2010)

\begin{tabular}{lccrrr}
\hline $\begin{array}{c}\text { Country } \\
\text { group }\end{array}$ & $\begin{array}{c}\text { Cut flowers and } \\
\text { indoor ornamental } \\
\text { plants (ha) }\end{array}$ & $\begin{array}{c}\text { Outdoor } \\
\text { ornamental } \\
\text { plants (ha) }\end{array}$ & $\begin{array}{c}\text { Flower } \\
\text { bulbs } \\
\text { (ha) }\end{array}$ & $\begin{array}{c}\text { Total ornamental } \\
\text { plants planted area } \\
\text { (ha) }\end{array}$ & $\begin{array}{c}\text { Rate } \\
(\%)\end{array}$ \\
\hline Europe & 52000 & 85000 & 25000 & 162000 & 11.38 \\
Middle East & 4100 & 1968 & 54 & 6122 & 0.43 \\
Africa & 16300 & - & - & 16300 & 1.15 \\
Asia-Pacific & 360000 & 526680 & 5398 & 892078 & 62.67 \\
North America & 18500 & 202645 & 2472 & 223617 & 15.71 \\
South America & 100000 & 23417 & - & 123417 & 8.67 \\
Total & 550900 & 839710 & 32924 & 1423534 & 100.00 \\
\hline
\end{tabular}

Source: Anon. 2011 
With the deregulation of indoor plants import, on the other hand, the demand for the cut flowers decreased dramatically in the domestic market as various imported indoor plants were introduced to the market (Yazgan et al. 2005).

Ornamental plants sector with an export value of about 73 million dollars together with processed products and by-products became an important economic activity for Turkey in 2012 (Anon. 2013).

Production area under ornamental plants shows a continual increasing tendency (Table 2). While total ornamental plants cultivation area was 1441.2 ha in the beginning of the 2000s, it has increased thrice to 4786 ha in 2011.

Regarding subsectors, according to the 2011 records, the production areas as percentage for outdoor ornamental plants, cut flowers, indoor ornamental plants, and flower bulbs were 73.28, $22.72,2.35$ and $1.65 \%$, respectively. Up to 2005 , cut flower production area took the first place but after 2005 outdoor ornamental plants area has been at the top.

The most rapid transition in the ornamental plants sector in Turkey occurred in the sector of outdoor ornamental plants. Increasing demand from government organizations for outdoor ornamental plants used for landscape arrangements of cities and building estates caused increase in the domestic demand after the 1990s. On the other hand, the fact that Turkish construction companies also carry out green arrangements in construction sites in Caucasia and Middle East has increased the additional demand for production of outdoor ornamental plants. In addition, development of the ornamental plants sector has also activated foreign trade. While ornamental plants export was about 12.9 million dollars in 2000 , it reached up to 73 million dollars in 2012. In addition, import of ornamental plants has showed a continuous increase when compared to that in 2000 (17.4 million dollars in 2000 to 67.7 million dollars in 2012) (Table 3).

Although in the last decade, the export and import of ornamental plants was floating, generally it has a tendency to increase after 2000. The ratio of exports to imports in ornamental plants sector has been fluctuating for years. In 2000 and 2006-2008, foreign trade deficit was seen but after 2009, foreign trade surplus was realized in parallel with high increase in export

Table 2. Ornamental plant production area in Turkey

\begin{tabular}{|c|c|c|c|c|c|c|c|c|c|c|}
\hline \multirow[t]{2}{*}{ Years } & \multicolumn{2}{|c|}{ Cut flowers } & \multicolumn{2}{|c|}{$\begin{array}{c}\text { Indoor } \\
\text { ornamental } \\
\text { plants }\end{array}$} & \multicolumn{2}{|c|}{$\begin{array}{c}\text { Outdoor } \\
\text { ornamental } \\
\text { plants }\end{array}$} & \multicolumn{2}{|c|}{ Flower bulbs } & \multicolumn{2}{|c|}{$\begin{array}{l}\text { Total production } \\
\text { Area }\end{array}$} \\
\hline & $\mathrm{Ha}$ & $(\%)$ & $\mathrm{Ha}$ & $(\%)$ & $\mathrm{Ha}$ & $(\%)$ & $\mathrm{Ha}$ & $(\%)$ & $\mathrm{Ha}$ & $(\%)$ \\
\hline 2000 & 854.5 & 56.47 & 54.2 & 3.58 & 591.5 & 39.09 & 13.0 & 0.86 & 1513.2 & 100.00 \\
\hline 2001 & 758.2 & 54.45 & 38.0 & 2.73 & 584.4 & 41.97 & 11.8 & 0.85 & 1392.4 & 100.00 \\
\hline 2002 & 1036.5 & 55.77 & 79.6 & 4.28 & 723.2 & 38.91 & 19.3 & 1.04 & 1858.6 & 100.00 \\
\hline 2003 & 1145.6 & 52.73 & 57.5 & 2.65 & 918.4 & 42.27 & 51.0 & 2.35 & 2172.5 & 100.00 \\
\hline 2004 & 1198.8 & 47.58 & 73.0 & 2.90 & 1193.4 & 47.37 & 54.3 & 2.15 & 2519.5 & 100.00 \\
\hline 2005 & 1220.3 & 48.29 & 78.5 & 3.11 & 1181.0 & 46.73 & 47.2 & 1.87 & 2527.0 & 100.00 \\
\hline 2006 & 1204.8 & 41.20 & 88.3 & 3.02 & 1574.3 & 53.83 & 57.0 & 1.95 & 2924.4 & 100.00 \\
\hline 2007 & 1263.9 & 42.30 & 125.0 & 4.18 & 1533.9 & 51.34 & 65.2 & 2.18 & 2987.9 & 100.00 \\
\hline 2008 & 1311.1 & 41.07 & 132.6 & 4.15 & 1673.8 & 52.43 & 75.1 & 2.35 & 3192.6 & 100.00 \\
\hline 2009 & 1543.4 & 41.08 & 176.9 & 4.71 & 1961.1 & 52.20 & 75.5 & 2.01 & 3756.9 & 100.00 \\
\hline 2010 & 1097.3 & 23.67 & 99.8 & 2.15 & 3385.3 & 73.01 & 54.3 & 1.17 & 4636.7 & 100.00 \\
\hline 2011 & 1087.4 & 22.72 & 112.7 & 2.35 & 3507.1 & 73.28 & 78.8 & 1.65 & 4786.0 & 100.00 \\
\hline $\begin{array}{l}\text { Index } 2011 \\
2000=100\end{array}$ & 127.3 & & 207.9 & & 592.9 & & 606.2 & & 316.3 & \\
\hline
\end{tabular}

Source: Anon. 2012 
Table 3. Export and import trends of ornamental plants in Turkey

\begin{tabular}{cccccr}
\hline Years & $\begin{array}{c}\text { Export } \\
(1000 \$)\end{array}$ & $\begin{array}{c}\text { Index } \\
(2000=100)\end{array}$ & $\begin{array}{c}\text { Import } \\
(1000 \$)\end{array}$ & $\begin{array}{c}\text { Index } \\
(2000=100)\end{array}$ & $\begin{array}{c}\text { Balance of trade } \\
(1000 \$)\end{array}$ \\
\hline 2000 & 12956 & 100.00 & 17482 & 100.00 & -4526 \\
2001 & 14282 & 110.23 & 10225 & 58.49 & 4057 \\
2002 & 22299 & 172.11 & 12288 & 70.29 & 10011 \\
2003 & 31486 & 243.02 & 15699 & 89.80 & 15787 \\
2004 & 37748 & 291.36 & 23505 & 134.45 & 14244 \\
2005 & 36230 & 279.64 & 33812 & 193.41 & 2417 \\
2006 & 40523 & 312.77 & 48621 & 278.12 & -8098 \\
2007 & 46447 & 358.50 & 52225 & 298.74 & -5778 \\
2008 & 45524 & 351.37 & 57750 & 330.34 & -12225 \\
2009 & 48613 & 375.22 & 37019 & 211.75 & 11594 \\
2010 & 56053 & 432.64 & 49757 & 284.62 & 6296 \\
2011 & 75957 & 586.27 & 67584 & 386.59 & 8372 \\
2012 & 73028 & 563.66 & 67716 & 387.35 & 5312 \\
\hline
\end{tabular}

Source: Anon. 2013.

Table 4. Conditions of outdoor ornamental plants production in Turkey and Konya province according to opinion of enterprise managers

\begin{tabular}{|c|c|c|c|c|}
\hline \multirow{3}{*}{ No. } & \multicolumn{4}{|c|}{ Significance level of factors that affect outdoor ornamental plants sector* } \\
\hline & \multicolumn{2}{|c|}{ Konya outdoor ornament plants } & \multicolumn{2}{|c|}{ Turkey outdoor ornament plants } \\
\hline & Factors & Score & Factors & Score \\
\hline 1 & Transportation opportunities & 3.6 & Transportation opportunities & 4.4 \\
\hline 2 & Geographic location & 3.1 & Geographic location & 4.3 \\
\hline 3 & Access to information sources & 3.1 & Access to information sources & 4.1 \\
\hline 4 & Wages and supply of labour & 3.1 & Wages and supply of labour & 4.1 \\
\hline 5 & Domestic consumption level & 3.1 & Domestic consumption level & 4.0 \\
\hline 6 & Marketing/storage/packaging & 2.9 & Marketing/storage/packaging & 3.8 \\
\hline 7 & Suitable soil structure & 2.7 & Suitable soil structure & 3.7 \\
\hline 8 & Product variability & 2.4 & Product variability & 3.7 \\
\hline 9 & Input costs & 2.2 & Input costs & 3.6 \\
\hline 10 & Capital structure of enterprises & 2.3 & Capital structure of enterprises & 3.3 \\
\hline 11 & Education level of sector employee & 2.1 & Education level of sector employee & 3.1 \\
\hline 12 & Suitable climate conditions & 2.0 & Suitable climate conditions & 3.0 \\
\hline 13 & Enterprise scale & 1.9 & Enterprise scale & 3.0 \\
\hline 14 & $\begin{array}{l}\text { Cultivation techniques and experience } \\
\text { level of sector }\end{array}$ & 1.9 & $\begin{array}{l}\text { Cultivation techniques and experience } \\
\text { level of sector }\end{array}$ & 2.9 \\
\hline 15 & Bureaucratic procedures-restrictions & 1.7 & Bureaucratic procedures-restrictions & 2.7 \\
\hline 16 & Production infrastructure & 1.4 & Production infrastructure & 2.6 \\
\hline 17 & Use of common advances technology & 1.3 & Use of common advances technology & 2.4 \\
\hline 18 & $\begin{array}{l}\text { Training activities with regard to } \\
\text { ornamentals }\end{array}$ & 1.3 & $\begin{array}{l}\text { Training activities with regard to } \\
\text { ornamentals }\end{array}$ & 2.3 \\
\hline 19 & Standardization & 1.2 & Standardization & 2.3 \\
\hline 20 & Research and development level & 1.2 & Research and development level & 2.0 \\
\hline 21 & Management structure & 1.0 & Management structure & 1.9 \\
\hline 22 & $\begin{array}{l}\text { Foreign Market Oriented Institutional } \\
\text { structure level }\end{array}$ & 1.1 & $\begin{array}{l}\text { Foreign Market Oriented Institutional } \\
\text { structure level }\end{array}$ & 1.9 \\
\hline
\end{tabular}

*5 - excellent, 4 - very good, 3 - good, 2 - fair, 1 - poor 


\section{The status of outdoor ornamental plants sector in Konya}

It has not been possible to examine the development of outdoor ornamental plants production in Konya province based only on statistic information. However, required information has been received through survey from managers of enterprises about the status and development of the outdoor ornamental plants sector. It has been discovered that public enterprises, particularly municipalities, have here pioneered development in outdoor ornamental plants production. Before the 2000s, households preferred traditional fruit trees for landscape arrangement outside their private houses and building estates. However, in the recent years, outdoor ornamental plants have substituted these traditional trees, and landscape arrangement approaches of municipalities have accelerated the development of the outdoor ornamental plants sector.

Most large companies producing outdoor ornamental plants are engaged in their trade on a large scale such as for large tenders but they do not sell plants in retail.

Managers of ornamental plants enterprises in the analysed Konya region are: 25-35 years old (12.5\%), 26-45 years old (25.0\%), $43.8 \%$ are in the age group of $46-55$ while $18.7 \%$ are 56 and above. The graduation levels of managers are: $6.3 \%$ of primary, $12.5 \%$ of secondary, $12.5 \%$ of high school and $68.7 \%$ of university education. Experiences of those managers are: $10-20$ years, $56.2 \%$ and more than 20 years, $43.8 \%$. The ownership of enterprises are: $31.2 \%$ private, $56.3 \%$ belonging to companies and $12.5 \%$ public. The average production area of enterprises was approximately $3.3 \mathrm{ha}$, including 0.1 ha glasshouses and foil tends. In general, outdoor ornamental plants have been produced in field while indoor ornamental plants have been cultivated in greenhouses. Commercial activities of enterprises as percentage for outdoor ornamental plants and indoor ornamental plants were determined as 91.1 and $8.9 \%$, respectively.

\section{SWOT analysis of outdoor ornamental plants sector in Konya province}

Most of the ornamentals in the Konya province are produced as outdoor ornamental plants. Fifty percent of enterprises producing outdoor ornamental plants were established in the 2000s. Outdoor ornamental plants sector has some advantages and disadvantages in the Konya province. According to the managers of the enterprises, the situation of the ornamental plants sector in Turkey is better in terms of various criteria. Managers stated that outdoor ornamental plants sector in the whole country has advantages due to transportation facilities, product patterns, geographical position, soil structure, climate conditions, easy access to information, labour cost, domestic consumption, enterprise scale, etc. On the other hand, it was specified that outdoor ornamental plants sector has disadvantages in the Konya province due to poor cultivation techniques and experience, poor marketing structure, some bureaucratic procedures, weak training activities, etc.

Using data from Table 4 and from literature, SWOT analysis was performed to indicate the current constraints and future possibilities of the ornamental plants sector in the Konya province (Table 5). The sector has strengths having advantages due to appropriate transport facilities, geographic location, suitable wages, well-trained enterprise managers, good relations of managers with stakeholders, etc. On the other hand, the sector has disadvantages due to not-so-favourable climatic conditions in all of Konya's regions, weak management techniques in enterprises, small-scale enterprises, narrow spectrum of cultivars, undereducated intermediate staff, etc.

Outdoor ornamental plants sector has opportunities such as increasing demand for ornamental plants in all segments of society, the existence of graduate and undergraduate programs in Konya province, continuing input supports, the existence of investment and research-development expenditures support. There are also threats to the sector due to changing demands with regard to political decision and lack of regulation on patent rights. 
Table 5. SWOT analysis of outdoor ornamental plants sector in Konya province of Turkey

\begin{tabular}{|c|c|}
\hline \multicolumn{2}{|c|}{ Internal Factors } \\
\hline Strengths & Weaknesses \\
\hline $\begin{array}{l}\text { - Transportation facilities are good. } \\
\text { - It is geographically close to important consumption } \\
\text { centres. } \\
\text { - Labour wages are reasonable. } \\
\text { - Increasing demand for outdoor ornamental plants. } \\
\text { - Departments related to landscape and environment } \\
\text { are available in universities. } \\
\text { - Directors of public institutions support and } \\
\text { encourage the sector. } \\
\text { - Increase in municipal sector support requests. } \\
\text { - Having microclimate regions to produce outdoor } \\
\text { ornamental plants. } \\
\text { - Education levels of Enterprise Directors are high. } \\
\text { - Managers of enterprises are open to relations and } \\
\text { cooperation. } \\
\text { - Managers of businesses have good relations with } \\
\text { enterprise managers in other countries and cities. }\end{array}$ & $\begin{array}{l}\text { - Climate conditions are not appropriate in all } \\
\text { regions of the province. } \\
\text { - Enterprises do not have organized structures. } \\
\text { - Some input costs are high. } \\
\text { - Inadequate capital structure. } \\
\text { - Product range is not considerable. } \\
\text { - Intermediate staff is insufficient and education } \\
\text { levels of available ones is low. } \\
\text { - Sector-oriented training activities are not adequate. } \\
\text { - Lack of standardization. } \\
\text { - Unsatisfactory research and development } \\
\text { expenditures in sector-oriented enterprises. } \\
\text { - Lack of institutional organization and infrastructure } \\
\text { for internal and external marketing. } \\
\text { - The number of cultivated outdoor ornamental } \\
\text { plants was limited. } \\
\text { - Storage, packaging and marketing problems. } \\
\text { - University-sector relationship and cooperation are } \\
\text { weak. }\end{array}$ \\
\hline
\end{tabular}

\section{External Factors}

\section{Opportunities}

Threats

- Demand for ornamental plants as environmental consciousness increases in all segments of society.

- Increasing interest and support of public and nongovernmental organizations for the sector.

- Undergraduate and associate degree programs regarding sector development in universities.

- Ministry of Food, Agriculture and Livestock arranges, encourages and supports the sector.

- Entrepreneurial supports are available.

- Construction companies operating in other countries prefer outdoor ornamental plants from Turkey.

- Encouragement and support increase for research and development.

- Presence of rich domestic genetic resources.
- Competition disadvantage of enterprises in Konya due to more appropriate climate and market conditions in Marmara, Aegean and Mediterranean Regions.

- Dependence on the supply of high-quality seedlings.

- Despite the continuous increase in input prices, commodity price fluctuations have led to uncertainty.

- Research-development structure has not been constituted to increase competitive power.

- Outdoor ornamental plants sectors in Marmara and Aegean regions have technical and economic superiority.

- Demand depends on public institution in sector and demand may change with regard to political decisions.

- Seedlings were sale at lower rates by public institutions.

- Lack of regulations concerning patent rights.

\section{Structural analysis of outdoor ornamental plants} sector in Konya province

The structural and competitive analysis is very complex to be explained only through labour force and capital superiorities. All factors affecting competitive force and mutual interactions of factors should be taken into account. Within this scope, competition level of outdoor ornamental plants 
sector has been analysed using five factors according to the Diamond model (Porter 1990; 2004). These factors are: inputs, company strategies and constitution structure, demand conditions, relative and support institutions and role of government. The government factor and demand conditions among the factors affecting competition level of outdoor ornamental plants sector were at the mid-level. In this case, the lowest score was obtained from legal arrangement since no legal arrangement exists at present.
On examination of firm strategies, structure and rivalry, the lowest scores were determined from size of enterprises, human resources and standard production as well as research and development activities. In addition, condition of factors and that of related supporting industries were at low level due to no supply of quality seedlings, energy cost, lack of an auction system and cluster, etc. (Fig. 1). All these factors have resulted in lesser competitiveness of outdoor ornamental plants production in Konya.

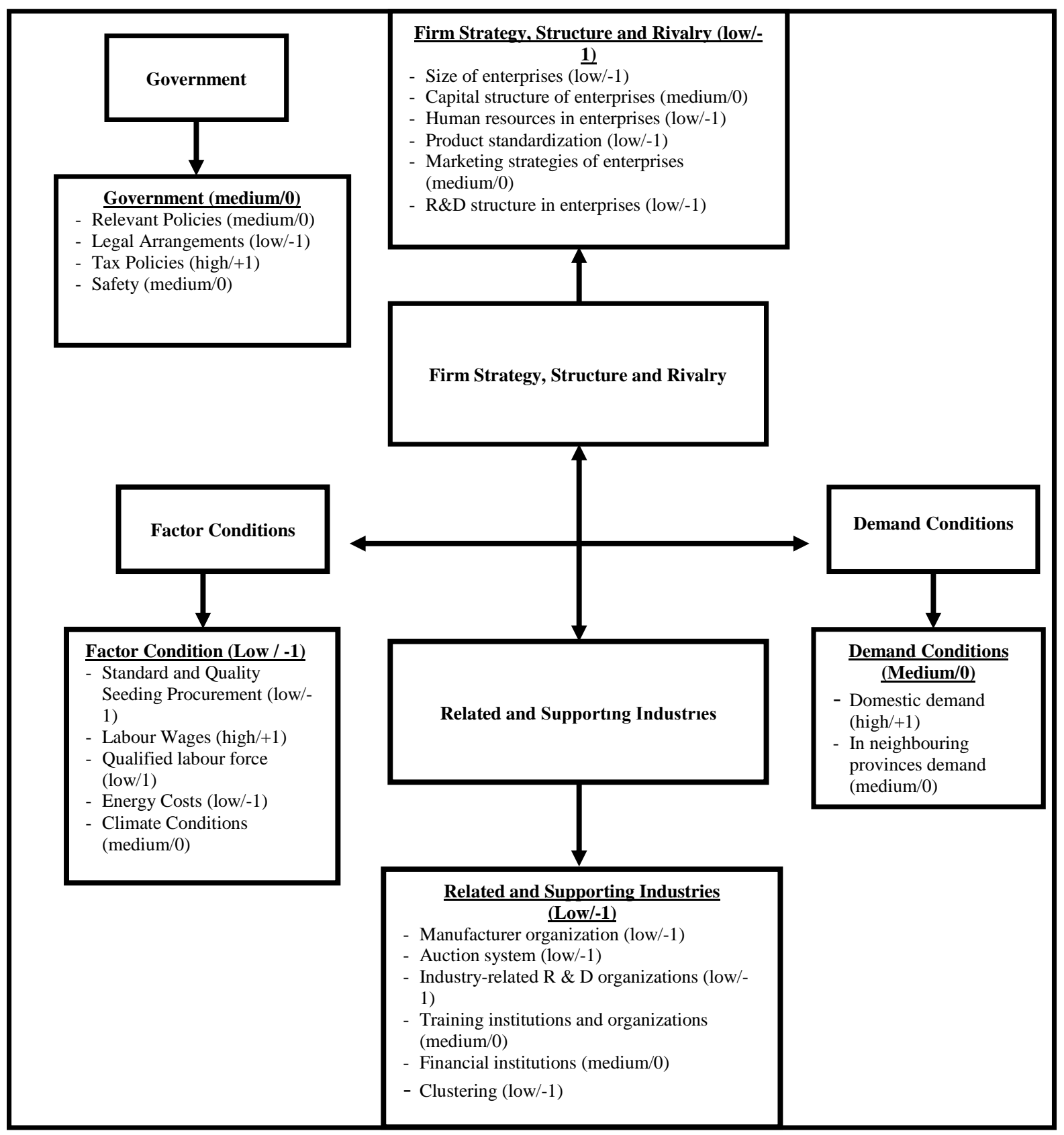

Fig. 1. The structural analysis of outdoor ornamental plants sector in Konya province 
Strategies for outdoor ornamental plants sectors in Konya province

Strategies proposed for the development of outdoor ornamental plants sector, competition level of which is low in Konya, have been structured with regard to the three general strategies model of Porter. Competitive power increasing strategies of enterprises in a sector is defined as "to get position in order to maximize abilities distinguishing company from its opponents" (Munive Hernandez et al. 2004). Developing a competition strategy is to make a general formula regarding how a company shall act, what targets it shall have and which policies are required to achieve these targets. According to Porter, basic strategies should be applied in order to make a difference in profit or performance against their opponents, for example, cost advantage, differentiation advantage, or clustering advantage (Porter 2003). While enterprises constitute components of these strategies, first, they should put forth strengths and weaknesses of enterprises and value of key executives as intra company factors. Then, they should determine economic and technical opportunities within the sector and more generally social expectations as factors out of company. Circumstances in question have been analysed in SWOT analysis, structural analysis, and conditions of enterprises producing outdoor ornamental plants in Konya. Items to be carried out for development of outdoor ornamental plants sector in Konya with regard to these three general strategies of Porter are indicated in Table 6 .

Table 6. Competition strategies of outdoor ornamental plants production in Konya province

\begin{tabular}{|c|c|c|}
\hline Strategy & Actions to be taken & Organizational requirements \\
\hline 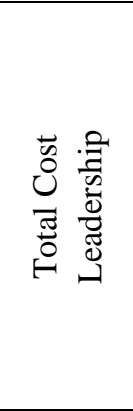 & $\begin{array}{l}\text { - To increase investment and working capital of } \\
\text { enterprises via financial sources with appropriate } \\
\text { conditions. } \\
\text { - Making product planning by considering various } \\
\text { product alternatives. } \\
\text { - Effective use of the labour force. } \\
\text { - Effective use of energy. } \\
\text { - To rationalize production techniques. } \\
\text { - To establish cheaper distribution system. }\end{array}$ & $\begin{array}{l}\text { - Keeping records. } \\
\text { - Effective planning and control. } \\
\text { - Establishment of cooperatives to } \\
\text { provide input. }\end{array}$ \\
\hline 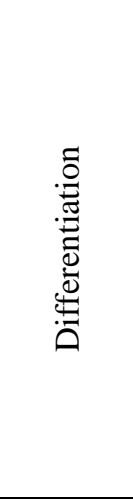 & $\begin{array}{l}\text { - To establish effective marketing system oriented } \\
\text { to market areas from which other cities are far. } \\
\text { - To cultivate natural area plants unique to the } \\
\text { region and to provide product differentiation. } \\
\text { - To think creatively in growing crops,. } \\
\text { - Branding of enterprises in developing quality and } \\
\text { product. } \\
\text { - To constitute different enterprise organizations } \\
\text { through combination of experiences in the city. } \\
\text { - To form a powerful cooperation through product } \\
\text { procurement and product marketing channels. }\end{array}$ & $\begin{array}{l}\text { - Strong coordination between research } \\
\text { and development departments and } \\
\text { producing and marketing departments. } \\
\text { - To set up research and development } \\
\text { substructure in big businesses. } \\
\text { - To establish institutional structures to } \\
\text { help in research and development. } \\
\text { - To market the creation of an auction } \\
\text { system. }\end{array}$ \\
\hline 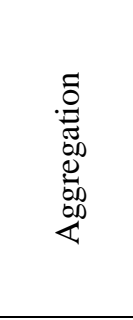 & $\begin{array}{l}\text { - To establish organized outdoor ornamental plants } \\
\text { region. } \\
\text { - To create suitable policies for the internal and the } \\
\text { external market objectives. } \\
\text { - To expand training activities to raise awareness in } \\
\text { order to increase contribution of enterprises to } \\
\text { aggregation. }\end{array}$ & $\begin{array}{l}\text { - To create cluster with stakeholders. } \\
\text { - To improve cooperation between sector } \\
\text { and universities. }\end{array}$ \\
\hline
\end{tabular}


A reduction in the cost, capital, labour, and energy must be used effectively in businesses. To do this, companies need to use advanced management techniques and establish cooperative enterprises. As alternative strategies, business managers should establish effective marketing systems, should be grow locally appropriate alternative products, and should be in good relations between business and $\mathrm{R} \& \mathrm{D}$ institutions. Also, clustering strategy must be based on establishment of organization policies, better definition of domestic and foreign market goals, and training activities to raise awareness in order to increase contribution of enterprises to aggregation.

\section{DISCUSSION}

The increase in the global human population in the last decades has been accompanied by a rapid rise in horticultural crop production (vegetables, fruits, wine, etc.), including the production of ornamental plants and flowers (Harrison 2003; Janick 2007). Developing countries are generally trying to develop horticultural industries to increase export revenues and to benefit rural communities (Warrington 2005; Lumpkin 2007).

Production of ornamental plants, including outdoor ornamentals, is continuing their development. Trade in these plants grows with the development of production techniques and the development of market structures. This sector generates revenues from import and contributes to an increase in employment. The outdoor ornamental plants production area, which was 591.5 ha in 2000, increased 7 times, to 3507.1 ha in 2011. Asciuto et al. (2008) stated that Turkey has improved its advantage in this sector in the last 10 years.

Konya province has developed all areas of economy. Development index, economic development index and social development index, as well as populations of Konya province were at the 17th, 9th, 23rd and 7th positions, respectively, among 81 provinces in Turkey. Local government studies carried out on "greening" buildings and building complexes, and surroundings within private residential areas, through environmental arrangements and green space policies, have gained momentum in recent years. As a result of these developments, the number of enterprises producing outdoor ornamental plants has increased by $50 \%$ since the beginning of 2000. However, when the outdoor ornamental plants sector of Konya is compared with the outdoor ornamental plants sector of the whole country, it has been specified that competition superiority does not exist and competitiveness is low. Appropriate climate conditions and high demand and local government supports in Marmara and Aegean Regions, where urban and economic development is high, have contributed to cultivation of ornamental plants and competitive power in these regions. It is thought that there exists a direct relationship between education level, gross national product value quota per capita, similar developmental scales, and development of ornamental plants sector (Dissart \& Deller 2000). Close proximity to the eastern provinces and climate similarities of Konya in Turkey provides advantages to meet the demand for outdoor ornamental plants. However, in Konya, inadequate production techniques, restricted capital of enterprises and impossibility to extend mechanization restrict mass production of outdoor ornamentals.

The fact that: enterprises within the outdoor ornamental plants sector in Konya rationalize their production techniques and provide financial advantage, that Central Anatolian Region focuses on outdoor ornamental plants appropriate for continental climate and creates product differentiation, and that enterprises making production in Konya tend towards aggregation strategies to ensure cost advantage and synergy will contribute to increase in the competitive power of this sector.

\section{REFERENCES}

Anonymous 2001. Eighth five-year development plan, agricultural production. Private Procurement Commission Ornament Plant Subcommission Report. http://ekutup.dpt.gov.tr (accessed 13.08.2013).

Anonymous 2011. AIPH International Statistical Yearbook. 
Anonymous 2012. Ministry of Food, Agriculture and Livestock Records, Ankara. www.tarim.gov.tr (accessed 06.07.2013).

Anonymous 2013. Ministry of Economy Records, Ankara. www.dpt.gov.tr (accessed 07.08.2013).

Asciuto A., Carapezza R., Galati A., Schimmenti E. 2008. The competitiveness of the Italian flower and ornamental plant sector. New Medit. 7: 26-37.

Ay S. 2009. Exportation of ornamental plants, problems and solution offers: a study in Yalova district. Journal of Suleyman Demirel University, Faculty of Economics and Administrative Sciences 14: 423-443.

Dissart J.C., Deller S.C. 2000. Quality of life in the planning literature. J. Plan. Lit. 15(1): 135-161. DOI: $10.1177 / 08854120022092962$.

Eşitken A., Çelik Y., Polat A.T., Karakayacı Z. 2012. Feasibility study oriented to outdoor ornamental plants, indoor ornamental plants, cut flowers and flower unions cultivation investments in Konya. TR Mevlana Development Agency, Konya.

Eraydın K., Gül E., Çevik B., Demir E. 2012. Investigation of the development level of provinces in Turkey.

http://ekonomi.isbank.com.tr/UserFiles/pdf/ar_03_ 2012.pdf. (Accessed 4.11.2013).

Harrison K.M. 2003. World trends driving horticultural expansion in emerging economies. Acta Hort. 621: $115-125$

Houben G.K., Lenie K., Vanhoof K. 1999. A knowledgebased SWOT analysis as an instrument for strategic planning in small and medium sized enterprises. Decision Support System 26: 125-135. DOI: 10.1016/S0167-9236(99)00024-X.

Janick J. 2007. The origins of horticultural technology and science. Acta Hort. 759: 41-60.

Karagüzel O., Korkut A.B., Özkan B., Çeliker F.G., Titiz S. 2010. Ornamental plants production and developing facilities and goals. Ankara, Turkey, 11-15 January 2010, Agricultural Engineering VII Technical Congress 1: 539-558.

Lumpkin T.A. 2007. Energizing global horticultural research for the developing world. Acta Hort. 759: 15-28.

Munive Hernandez E.J., Dewhurst F.W., Pritchard M.C., Barber K.D. 2004. Modelling the strategy management process: an initial BPM approach. Journal of Business Process Management 10,6: 691-711. DOI: 10.1108/14637150410567884.
Özen F., Kılınç M., Uz S. 1998. Ornamental plants in Samsun Ondokuz May1s University Campus. Journal of Environmental Protection 7(27): 26-30.

Porter M. 1990. The competitive advantages of nations: creating and sustaining superior performance. The Macmillan Press Ltd., London and Basingstoke.

Porter M. 2003. Competition strategy sector and competition analysis techniques. Gülen Ulubilgen, Sistem Publishment, Istanbul.

Porter M. 2004. Building the microeconomic foundations of prosperity: findings from the business competitiveness index. Global Competitiveness Report 2003-2004, World Economic Forum.

Sayın B., Sayın C. 2004. Evaluation of production and marketing structure of Turkey ornamental plants in terms of compliance with EU. Tokat, Turkey, 1618th September, VI Agricultural Economics Congress.

Subaşı O.S., Yeler O., Yatkın E. 2012. Ornamental plants sector, access to international market. Mersin Flora, Ornamental Plants Project Report.

Taşçıŏlu Y. 2003. Evaluation of cut flower production and export structure oriented to export in Antalya. Akdeniz University, Institute of Science, Agricultural Economics Department, Post Graduate Thesis, Antalya.

Temel M. 2011. Structure of ornamental plants in Yalova province, production facilities, problems and solution offers. Namik Kemal University, Institute of Science, Agricultural Economics Department, Post Graduate Thesis, Tekirdağ.

Titiz S., Çakıroğlu, N., Yıldırım T., Çakmak., S. 2000. Developments in production and commerce of ornamental plants. TMMOB Agriculture Engineer Chamber, Agricultural Congress 1: 709-740.

Warrington I. 2005. Building bridges and enhancing economic potential. Acta Hort. 694: 215-221.

Yazgan M.E., Korkut A.B., Barış E., Erkal S., Yılmaz R., Erken K., Gürsan K., Özyavuz M. 2005. Developments in ornamental plants production. TMMOB Agriculture Engineer Chamber, Türkiye Agricultural Engineering VI Technical Congress 1: 589-607.

Yilmaz İ. 2009. SWOT analysis of Turkish cut flower sector in EU harmonization process. Akdeniz University, Journal of Agricultural Faculty 22(1): 103-112.

Yumuk G., İnan İ.H. 2005. Evaluation of cost of quality of industry companies through SWOT analysis in Thrace region, Turkey. Journal of Tekirdag Agricultural Faculty 2(2): 177-188. 
Zencirkıran M., Gürbüz İ.B. 2009. Turkish ornamental plants sector in the European Union screening process. J. Fruit Ornam. Plant Res. 17(2): 235-250.

Zoller C., Bruynis C. 2007. Conducting a SWOT analysis of your agricultural business. Ohio State University
Extension Fact Sheet Series.

http://ohioline.osu.edu/bst-fact/pdf/3611.pdf (accessed 23.07.2013). 